\title{
KEBUTUHAN INFORMASI DI TENGAH WABAH PANDEMI COVID 19 SEBUAH PENDEKATAN KEPUSTAKAAN DI IAIN BENGKULU
}

\author{
MERDANSAH, S.HI.,MH \\ PUSTAKAWAN IAIN BENGKULU \\ merdansahh@gmail.com
}

\begin{abstract}
Abstrak:
Corona virus19 adalah suatu kelompok virus yang dapat menyebabkan penyakit pada hewan atau manusia. Beberapa jenis corona virus diketahui menyebabkan infeksi saluran nafas pada manusia mulai dari batuk pilek hingga yang lebih serius seperti Middle East Respiratory Syndrome (MERS) dan Severe Acute Respiratory Syndrome (SARS). Kebutuhan informasi adalah suatu kebutuhan data yang telah diolah menjadi yang lebih berguna, lebih berarti dan bermanfat bagi yang menggunakannya. Memahami kebutuhan informasi pemakai memerlukan kerjasama antara pengelola informasi dan pemakai informasi. Memastikan kebutuhan informasi pemakai merupakan suatu fenomena yang rumit bahkan pemakai informasi sendiri sangat merasa kesulitan dalam mengungkapkan dan mengidentifikasi kebutuhan mereka, apalagi ditengah masa sulit pandemi sekarang ini.
\end{abstract}

Keyword. Kebutuhan Informasi, Coronavirus 19

\begin{abstract}
Corona virus19 is a group of viruses that can cause disease in animals or humans. Several types of coronavirus are known to cause respiratory infections in humans ranging from cold coughs to more serious ones such as Middle East Respiratory Syndrome (MERS) and Severe Acute Respiratory Syndrome (SARS). Information needs are data needs that have been processed to be more useful, more meaningful and useful for those who use them. Understanding user information needs requires collaboration between information managers and information users. Ensuring user information needs is a complex phenomenon and even users of information themselves find it very difficult to express and identify their needs, especially amid the difficult times of the current pandemic.
\end{abstract}

Keyword. Information need, Coronavirus 19

\section{PENDAHULUAN}

Wabah pandemi virus corona (Covid19) menjadi salah satu pandemi paling berbahaya baru-baru ini. Virus ini telah menyebar secara masif dihampir seluruh belahan dunia update 25 Oktober 2020 lebih kurang 45 Juta penduduk dunia pada saat ini terjangkit, sembuh lebih kurang 29,8 juta dan meninggal dunia lebih kurang 1,19 juta. Bahkan Indonesia pada saat ini sudah mencapai angka 410 ribu orang yang sudah terjangkit, sembuh 338 ribu dan meninggal dunia 13, 869 orang.
Virus corona (Covid19) adalah suatu kelompok virus yang dapat menyebabkan penyakit pada hewan atau manusia. Beberapa jenis corona virus diketahui menyebabkan infeksi saluran nafas pada manusia mulai dari batuk pilek hingga yang lebih serius seperti Middle East Respiratory Syndrome (MERS) dan Severe Acute Respiratory Syndrome (SARS). Coronavirus jenis baru yang ditemukan menyebabkan penyakit Covid-19 ${ }^{1}$. Berbagai

\footnotetext{
Tedros Adhanom, 2020. Dirjen World Health Organization (WHO). Jenewa Swiss
} 
langkah dan upaya telah dilakukan untuk memutus rantai penyebaran virus corona seperti Lockdown (karantina wilayah), Pembatasan Sosial Berskala Besar (PSBB) atau Social Distancing, hingga Work From Home bagi seluruh ASN (PNS dan PPPK) dan pegawai swasta serta seluruh masyarakat telah diterapkan diberbagai daerah di Indonesia ${ }^{2}$. Hal ini adalah bentuk usaha pemerintah untuk mencegah dan memutus rantai penyebaran Virus Corona.

Indonesia sangat terdampak luas terhadap beberapa sektor akibat adanya covid 19, salah satunya unsur pendidikan siswa dan mahasiswa yang diwajibkan belajar di rumah saja. Untuk menjaga keberlangsungan proses belajar mengajar dari rumah pemerintah menganjurkan seluruh yang berprofesi Guru, Dosen dan Pustakawan dapat melayani siswa dan mahasiswa dengan system on line elektronik menjadi pilihan yang tepat. Profesi guru saat ini menjadi garda terdepan dalam melakukan kegiatan mencerdaskan kehidupan bangsa tidak terlepas juga pustakawan yang menjadi penopang kelancaran kegiatan proses belajar mengajar dari rumah tersebut.

Lalu tersirat dalam pikiran orang bahwa bagaimana dengan pustakawan sebagai agen informasi untuk melayani mengahadapi pemustaka dalam menghadapi situasi saat ini dan apa bisa menyampaikan dan menginformasikan kepada pemustaka yang bisa membantu para

\footnotetext{
2 Doni Monardo, 2020. Badan Nasional Penanggulangan Bencana/Ketua Satgas penanganan Covid 19. Jakarta.
}

pemustaka jarak jauh yang bisa membagikan informasi yang benar dalam melakukan layanan karya cetak menjadi referensi dalam membantu anak-anak dalam mengerjakan tugas-tugas

yang diberikan oleh guru dan dosen. Informasi adalah data yang diolah menjadi bentuk yang lebih berguna, lebih berarti dan bermanfaat bagi penggunanya, sedangkan data menggambarkan kenyataan dan kesatuan yang nyata sebagai reperesentasi dunia nyata yang mewakili suatu objek tertentu seperti manusia, hewan, peristiwa konsep, keadaan dan lain-lain. Dalam konteks ilmu perpustakaan, dalam usaha melakukan manajemen informasi, langkah awal yang dilakukan adalah identifikasi kebutuhan informasi, kata kebutuhan dapat diartikan sebagai sesuatu yang harus dimiliki sesorang sehingga kebutuhan informasi dapat diartikan informasi yang dimiliki seseorang.

\section{METODE}

Desain penelitian yang digunakan adalah desain kualitatif deskriftif. Menuruta Bogdan dan Taylor dalam Moleong, penelitian kualitatif sebagai prosedur penelitian yang menghasilkan data deskriptif berupa kata-kata tertulis atau lisan dari orang-orang dan perilaku yang dapat diamati. ${ }^{3}$ Senada dengan definisi tersebut Kirk dan Miller dalam Moleong mendefinisikan juga penelitian kualitatif adalah tradisi tertentu dalam ilmu pengetahuan social yang secara fundamental bergantung dari pengamatan pada manusia

\footnotetext{
${ }^{3}$ Lexi JMoleong.2010. Metodologi Penelitian Kualitatif. Bandung: PT. Remaja Roskakarya
} 
baik dalam kawasannya maupun dalam peristilahannya. Berdasarkan dua pengertian diatas, dapat disimpulkan bahwa penelitian kualitatif adalah penelitian yang bermaksud untuk memahami subjek yang akan diteliti, missal prilaku, persepsi, motivasi dan tindakan dalam bentuk kata-kata dan bahasa dengan memanfaatkan berbagai metode. Adapun pendekatan yang digunakan dalam penelitian ini adalah pendekatan deskriptif. Menurut Arikunto, pendekatan ini hanya menggambarkan "apa adanya" tentang suatu variable, gejala atau keadaan. Pendekatan deskriptif mencoba mencari deskriptif yang tepat dan cukup dari semua aktivitas, objek dan manusia. ${ }^{4}$ Dalam pendekatan deskriptif kualitatif data yang dikumpulkan adalah berupa kata-kata dan gambar bukan angka-angka.

\section{PEMBAHASAN}

Secara umum pengertian informasi adalah sekumpulan data atau fakta yang telah diproses dan dikelola sedemikian rupa sehingga menjadi sesuatu yang mudah dimengerti dan bermanfaat bagi penerimanya. Dari definisi tersebut dapat kita pahami bahwa kata "informasi" memiliki arti yang berbeda dengan kata "data". Data adalah fakta yang masih bersifat mentah atau belum diolah, setelah mengalami proses atau diolah maka data itu bisa menjadi suatu informasi yang bermanfaat.Tidak semua data atau fakta dapat diolah menjadi sebuah informasi bagi penerimanya. Jika suatu data yang diolah temyata tidak bermanfaat bagi penerimanya, maka hal

\footnotetext{
${ }^{4}$ Suharsimi Arikunto.2013. Manajemen Penelitian. Jakarta: PT. Asdi Mahasatya
}

tersebut belum bisa disebut sebagai sebuah informasi.

Namun secara etimologis istilah informasi berasal dari bahasa latin, yaitu Informatinem yang artinya ide, kode, atau garis besar. ${ }^{5}$. Informasi dapat disajikan dalam beragam bentuk, mulai dari tulisan, gambar, tabel, diagram, audio, video, dan lain sebagainya.

Menurut Jogiyanto HM, pengertian informasi adalah hasil dari pengolahan data ke dalam bentuk yang lebih bermanfaat bagi penerimanya yang menggambarkan kejadiankejadian yang nyata untuk digunakan dalam pengambilan keputusan ${ }^{6}$. Para peneliti berbeda konsep Setidaknya ada tujuh fungsi informasi bagi manusia. Adapun beberapa fungsi informasi adalah sebagai berikut::

1. Menjadi sumber pengetahun baru

Pentingnya ketersediaan informasi yang valid ketika didapatkan oleh seseorang dapat menjadi pengetahuan baru dan menambah wawasan di bidang tertentu. Misalnya informasi mengenai cara mengatasi masalah kesehatan yang didapatkan dari konten di internet. Mungkin informasi tersebut adalah sesuatu yang umum dan sudah banyak diketahui orang. Namun, mungkin saja ada seseorang yang belum mengetahui informasi tersebut.

2. Menghapus Ketidakpastian

Minimya informasi tentang sesuatu akan menimbulkan ketidakpastian. Untuk

\footnotetext{
${ }^{5}$ Kamu Besar Bahasa Indonesia, Jakarta. 2008

${ }^{6}$ Jogiyanto HM, Analisis dan Desain system informasi, Pendekatan terstruktur teori dan praktek, Andi Yogyakarta, 2005: 15
} 
menghapus ketidak pastian tersebut maka diperlukan informasi lengkap dan valid dari sumber terpercaya dan akurat.

3. Sebagai media hiburan

Keberadaan informasi juga dapat berfungsi sebagai media hiburan bagi masyarakat, misalnya informasi mengenai objek wisata di suatu tempat yang disajikan dengan bahasa dan gambar-gambar yang menarik.

4. Sebagai sumber berita

Sebuah informasi mengenai hal tertentu bisa dipakai sebagai sumber berita yang disampaikan kepada khalayak. Misalnya informasi tentang Covid 19 diberbagai daerah Indonesia yang di dapatkan dari media Televisi, Radio dan situs berita online.

5. Untuk sosialisasi kebijakan

Informasi adalah komponen penting dalam berkomunikasi dengan pihak lain. Salah satunya adalah untuk menyampaikan suatu kebijakan dari pemerintah kepada masyarakat yang dilakukan dengan cara sosialisasi.

6. Untuk mempengaruhi khalayak

Penyampaian informasi melalui media massa biasanya dilakukan untuk mempengaruhi khlayak. Misalnya informasi mengenai suatu produk melalui Televisi yang tujuannya agar masyarakat mengenal dan tertarik untuk menggunakannya.

7. Menyatukan pendapat
Pada era media sosial (online) seperti sekarang ini sangat mudah untuk menyampaikan pendapat ke ruang publik. Namun tidak semua pendapat tersebut sesuai dengan fakta yang ada. Adanya informasi yang valid dari sumber terpercaya akan bermanfaat untuk menilai setiap pendapat yang dikemukakan di ruang publik apakah sesuai dengan informasi tersebut.

\section{Analisis Kebutuhan Informasi}

Menurut Koswara $^{7}$ urgensi melakukan analisis kebutuhan informasi secara umum adalah sebagai berikut :

1. Meningkatkan jumlah pemakai informasi

2. Semakin berkembangnya ilmu pengetahuan, teknologi, dan industry

3. Meningkatkan spesialisasi bersamaan dengan meningkatnya keterkaitan dan ketergantungan antara berbagai cabang ilmu pengetahuan.

4. Kerjasama antar Negara dalam skala besar dalam bidang perkembangan ilmu pengetahuan, teknologi dan industry

5. Kesibukan pemakai informasi yang semakin tinggi dan komprehensiv

6. Perilaku pemakai informasi yang heterogen (umur pangkat jabatan, bidang keilmuan, pekerjaan).

Dalam konteks ilmu perpustakaan, dalam usaha melakukan manajemen informasi, langkah

\footnotetext{
${ }^{7}$ Koswara,E.1998. Dinamika informasi dalam era global, Bandung: IPI Remaja Rosdakarya. Jabar 103
} 
awal yang dilakukan adalah identifikasi kebutuhan akan informasi. Devadason menjelaskan tentang pentingnya melakukan identifikasi kebutuhan informasi pengguna sebagai berikut ${ }^{8}$ :

"Identification of information needs is essential to design of information systems in general and to the provison of effective information service in particular. But it has been found to be a difficult task as it is almost an investigative or detective work. In order to identify information needs one should adopt various methods to gather information on the various factors that influence the information needs. No single methode or tool will sere entirely. A careful selection and blending on the user whose need is being studied is necessary".

Dapat di lihat secara umum mengidentifikasi kebutuhan informasi merupakan sesuatu yang esensial didalam meracang sistem informasi dan secara khusus untuk menyediakan layanan informasi yang efektif. Tetapi merupakan tugas yang sulit dalam hal investigasi atau pekerjaan seseorang detektif. Untuk menegetahui kebutuhan informasi seseorang mestilah menggunakan berbagai metoda untuk memperoleh informasi dalam berbagai faktor yang dapat mempengaruhi kebutuhan informasi. Tidak ada satu metoda pun atau yang dapat memenuhi hal tersebut sama sekali. Sebuah seleksi yang hati-hati dan memadukan berbagai teknik yang akan dipilh

\footnotetext{
8 Devadson, FJ. 1996. Methodology for the identification of information needs of users. 62nd IFLA Generation conference-Conferenc proceeding, 25-31
}

bergantung kepada pengguna yang memrlukan untuk diteliti.

Adapun manfaat sesorang memahami kebutuhan informasi pemakai sebenarnya untuk mengetahui hal antara lain :

a. Siapa pemakai potensial perpustakaan

b. Apa yang mereka pelajari dan teliti

c. Sumber informasi dan layanan perpustakaan apa yang mereka butuhkan

d. Bagaimana pengetahuan mereka tentang sumber informasi dan layanan yang ada di perpustakaan

e. Bagaimana mereka menggunakan sumber informasi dan perpustakaan, dan;

f. Bagaimana merek menjadikan perpustakaan sebagai nilai tambah dalam membantu menyelesaikan tugas dan pekerjaan ${ }^{9}$.

Pada saat wabah pandemi covid 19 yang masih merajalela saat ini tentunya dalam pelayanan di civitas akademika IAIN Bengkulu sedikit terganggu, dikarenakan layanan menggunakan daring terlebih layanan di pusat perpustakaan seharusnya didasarkan kepada pemahaman tentang layanan terhadap kebutuhan dan keinginan informasi masyarakat pengguna dengan tetap menjunjung protokol kesehatan yang dikeluarkan oleh WHO dalam menyampaikan informasi kepada pengguna.

Pendekatan yang dapat dilakukan untuk mengetahui karakteristik dan perilaku pemakai dari suatu jasa perpustakaan secara sistematis adalah dengan kajian pemakai (user studies).

\footnotetext{
${ }^{9}$ October Hiller. 2004. Information seeking behavior in a changing learning environment, Information Research, Florida, 2
} 
Kajian pemakai banyak dipengaruhi ilmu psikologi dan sosiologi ${ }^{10}$. Ilmu psikologi menjelaskan faktor internal manusia melalui perilaku manusia, dalam kajian pemakai difokuskan pada perilaku manusia terhadap informasi. Aspek sosiologi menjelaskan perilaku manusia sebagai anggota masyarakat sangat dipengaruhi oleh kedudukan manusia di antara komunitasnya.

\section{Identifikasi Kebutuhan Informasi Di Tengah Pandemi Covid 19}

Untuk dapat mengidentifikasi kebutuhan informasi kepada masyarakat tentulah tidak semudah apa yang kita bayangkan terlebih pada saat pandemi covid 19 yang masih menjadi momok menakutkan bagi setiap manusia di dunia terlebih di Indonesia yang sampai saat ini vaksin virus tersebut belum juga ditemukan. Maka sudah menjadi suatu kewajiban bagi kita (Dosen, Guru, ASN, PPK dan Pustakawan) menjadi mediator penyamapain informasi kepada pengguna untuk dapat di akses baik secara tatap muka maupun secara daring (online). Dalam hal identifikasi kebutuhan informasi ini seorang pakar informasi Laloo beliau membagi identifikasi jenis kebutuhan informasi sebagai berikut:

1. Conceptual information

2. Emperical information

3. aprocedural information

4. Policy information

${ }^{10}$ Darmono dan Ardoni. 1994. Kajian pemakai dan sumbangannya kepada dunia Pusdokinfo. Jurnal ilmu perpustakaan dan informasi (2) April 21-34
5. Directive information ${ }^{11}$

Seiring dengan waktu akan kebutuhan informasi bagi sesorang untuk dapat memanfaatkan informasi dengan sebaik-baiknya, maka akan didapatkan adanya jenis identifikasi informasi tersebut diatas. Devadson seorang ahli informasi menjelaskan ada tujuh langkah dalam memahami kebutuhan informasi antara lain sebagai berikut:

1. Study of subject of interes to the organisation

2. Study of the organisation and its environment

3. Study of the immediate environment

4. Study of the user

5. Formal interview

6. Identification and recording of information needs

7. Analysis and refenement of the identified information needs ${ }^{12}$.

Setelah adanya identifikasi informasi maka seseorang dapat menerima informasi yang disampaikan untuk dapat diterima sebagai pemenuhan kebutuhan sesuai dengan apa yang akan dilakukannya. Langkah utama dalam proses mengidentifikasi kebutuhan informasi adalah sebagai berikut:

1. Mengkaji subyek-subyek yang diperlukan pengguna maupun organisasi

2. Mengkaji organisasi dan lingkungannya

3. Mengkaji lingkungan pengguna

\footnotetext{
11 Laloo, Bikika Tariang, 2002. Information needs, information seeking behaviuor an user. New Delhi: 23

${ }^{12}$ Devadson1996. Methodology for the identification of information needs of users. 62nd IFLA Generation conference-Conferenc proceeding, 41
} 
Almaktabah Vol. 5, No. 2, Desember 2020

4. Mengkaji pengguna

5. Melakukan interview

6. Mengindentifikasi dan mencatat kebutuhan informasi

7. Menganalisa dan memurnikan identifikasi kebutuhan informasi. ${ }^{13}$

Pendapat diatas menjadi suatu treaning bagi insan manusia untuk memenuhi kebutuhan informasi yang diperlukannya terlebih dalam masa wabah pandemi covid 19 yang belum berakhir, hal ini bila ke tujuh pendapat Devadson tersebut bila diterapkan di civitas akademika IAIN Bengkulu maka dapat dianalogikan sebagai berikut:

1. Kebutuhan informasi dalam bidang pekerjaan di IAIN Bengkulu walaupun dilakukan WFH (Work From Home)

2. Kebutuhan informasi dalam bidang disiplin ilmu sesuai dengan mata kuliah yang diampu Dosen dan minat mahasiswa IAIN Bengkulu serta penerapan pembelajaran daring (Online) bagi mahasiswa yang dilakukan Dosen dan pustakawan melalui WFH (Work From Home)

3. Kebutuhan informasi mengenai fasilitas yang tersedia di IAIN Bengkulu, Wifi, serta link tentang kegiatan perkuliahan,

4. Kebutuhan informasi untuk mendukung posisi pada Civitas akademika di IAIN Bengkulu, adanya link siakad, link SMPB, Link

5. Faktor-faktor motivasi pendorong dalam memenuhi kebutuhan informasi untuk

\footnotetext{
${ }^{13}$ Ibid 34
}

menemukan sesuatu penemuan baru di IAIN Bengkulu

6. Kebutuhan informasi untuk membuat suatu keputusan yang tepat di IAIN Bengkulu dan Kebutuhan informasi untuk mencari ide-ide baru di IAIN Bengkulu

7. Kebutuhan informasi dalam mencari kebenaran tentang sesuatu masalah serta memberikan masukan yang propesional bagi kemajuan IAIN Bengkulu

Dengan penjelasan diatas antara teori dan praktek yang menempatkan posisi dimana seseorang dapat melaksanakan kegiatan dalam pemenuhan kebutuhan informasi pada sebuah organisasi agar dapat berjalan sesuai dengan peraturan perundang-undangan yang berlaku. Hal inilah yang dapat menjadi suatu perhatian kita akan kebutuhan informasi yang sangat membantu dalam menggapai apa yang diinginkan dapat berjalan dengan baik sesuai apa yang menjadi suatu keharusan yang diinginkan oleh setiap insan manusia walaupun dalam kondisi apapun. Kebijakan yang diterapkan di Civitas akademika IAIN Bengkulu tetap melakukan pembelajaran sistem daring (Online) yang diterapkan kepada seluruh mahasiswa baik proses pembelajaran, bimbingan, penelitian bahkan $\mathrm{KKN}$ yang menjadi kewajiban bagi seluruh civitas akademika sesuai dengan protokol kesehatan yang berlaku.

\section{Faktor Yang Mempengaruhi Kebutuhan Informasi Di Tengah Covid 19}

Faktor yang paling umum mempengaruhi kebutuhan informasiadalah pekerjaan, termasuk 
kegiatan profesi, disiplin ilmu yang diminati, kebiasaan dan lingkungan pekerjaan. ${ }^{14}$ Menurut pendapat Laloo, kebutuhan informasi adalah sesuatu yang sebaiknya dimiliki sesorang dalam melakukan pekerjaannya penelitian, pendidikan dan juga sebagai hiburan ${ }^{15}$. Lain halnya dengan pendapat Devadson, menyatakan bahwa kebutuhan informasi tergantung pada kegiatan pekerjaan, disiplin ilmu, tersedianyan berbagai fasilitas, jenjang jabatan individu, faktor motivasi terhadap kebutuhan informasi, kebutuhan untuk mengambil keputusna, kebutuhan untuk mengambil keputusan, kebutuhan untuk mencari gagasan baru,kebutuhan untuk mendapat informasi yang tepat, kebutuhan untuk memberi kontribusi yang profesional, dan kebutuha untuk melakukan penemuan baru ${ }^{16}$.

Ada lima faktor yang mempengaruhi kebutuhan informasi pemakai antara lain:

a. Jenis pekerjaan

b. Personalitas yaitu aspek psikologi dari pencari informasi, meliputi ketepatan, ketekunan mencari informasi pencarian secara sistematis, motivasi dan kemauan menerima informasi dari teman, kolega dan atasan

c. Waktu,

d. Akses yaitu menelusur informasi secara internal (di dalam organisasi) atau eksternal (di luar orgaisasi) dan

\footnotetext{
${ }^{14}$ Atherton, P. 1977. Handbook for information systems and services. Paris: UNESCO

15 Laloo, Bikika Tariang, 2002. Information needs, information seeking behaviuor an user. New Delhi: 12

${ }^{16}$ Devadson. 1996. Methodology for the identification of information needs of users. 62nd IFLA Generation conference-Conferenc proceeding.
}

e. Sumber daya teknologi yang digunakan untuk mencari informasi. ${ }^{17}$

\section{KESIMPULAN}

Dari penjelasan beberapa pendapat para pakar di atas dapat ditarik suatu kesimpulkan bahwa sumber informasi merupakan segala macam informasi yang bias diawasi, dikendalikan, diolah dan dikelola oleh perpustakaan untuk seluruh pengguna yang ingin memenuhi kebutuhann baik informasi ilmiah maupun non ilmiah sedangkan pengguna informasi adalah mahasiswa, dosen, dokter, pengamat, masyarakat umum dan seluruh pengunjung perpustakaan IAIN Bengkulu yang bertujuan untuk memperoleh informasi di tengah wabah pandemi covid 19 dengan tetap menerapkan protokol kesehatan agar senantiasa kita dalam lindunganNya untuk beraktifitas menjalankan tugas sebagaimana biasanya.

\section{DAFTAR PUSTAKA}

Azhar Susanto. 2013. Sistem Informasi Akuntansi Lengkong. Bandung, 7

Atherton, P. 1977. Handbook for information systems and services. Paris: UNESCO

Chaudry. 1993. Information needs and their satifaction in a utility company.Library Review. AS. 42

Devadson, FJ. 1996. Methodology for the identification of information needs of

users. 62nd IFLA Generation conferenceConferenc proceeding, August, 25-31

Darmono dan Ardoni. 1994. Kajian pemakai dan sumbangannya kepada dunia

\footnotetext{
17 Koswara,E.1998. Dinamika informasi dalam era global, Bandung: IPI Remaja Rosdakarya. Jabar
} 
Almaktabah Vol. 5, No. 2, Desember 2020

Pusdokinfo. Jurnal ilmu perpustakaan dan informasi (2) april, 21-34

Doni Monardo, 2020. Badan Nasional Penanggulangan Bencana (BNPB)

/Ketua Satgas penanganan Covid 19. Jakarta. Jogiyanto HM. 2005. Analisis dan

Desain system informasi, Pendekatan terstruktur teori dan praktek Andi Yogyakarta, 15

Kamu Besar Bahasa Indonesia. 2008

Koswara, E . 1998. Dinamika informasi dalam era global, Bandung: IPI Remaja Rosdakarya. Jabar

Laloo, Bikika Tariang. 2002. Information needs, information seeking behaviuor an user. New Delhi: 12

Lexi J. Moleong. 2010. Metodologi Penelitian Kualitatif. Bandung: PT. Remaja Ros-

kakarya

Pendit, Putu Laxman. 2008. Prilkau Informasi semesta pengetahuan. Jakarta 24

Suharsimi Arikunto.2013. Manajemen Penelitian. Jakarta: PT. Asdi Mahasatya Sri Punomowati, 1995. Kebutuhan informasi dan perilaku pencarian informasi tenaga penelitian dan pengembangan di kalangan industri strategis. Jakarta, PDII LIPI. 57

Tedros Adhanom, 2020. Dirjen World Health Organization (WHO). Jenewa Swiss

October Hiller. 2004. Information seeking behavior in a changing learning environment, I nformation Research. Florida, 2 